\title{
Essential oils: a review on their salient biological activities and major delivery strategies
}

\author{
Sujata Paul, El Bethel Lalthavel Hmar, James H. Zothantluanga, Hemanta Kumar Sharma* \\ Department of Pharmaceutical Sciences, Faculty of Science and Engineering, Dibrugarh University, Dibrugarh 786004, Assam, India
}

\begin{abstract}
Essential oils are volatile, complex products of plants as secondary metabolites and include terpenes and their oxygenated derivatives, such as alcohols, aldehydes, esters, ketones, phenols and oxides. In recent years, out of 3000 essential oils obtained from plant origin only 300 essential oils have gained extensive attention for applications in various fields. In this review, we discuss the major biological activities associated with EOs as antimicrobial, antispasmodic, antioxidant, antiviral, anti-inflammatory, anthelmintic, insecticidal, antiparasitic, and cytotoxic agents. Different routes for delivery of essential oil along with the problems associated with essential oils like high volatility, low stability, permeability, bioavailability, poor water solubility, susceptibility to oxidation, decomposition, photosensitization and skin irritation are also highlighted. Furthermore, strategies to solve the mentioned problems are suggested by different nanoencapsulating systems. These include polymer-based nanocarriers, lipid-based nanocarriers and molecular complexes. It is believed that nanoencapsulation of essential oils will improve their therapeutic activity and delivery.
\end{abstract}

Keywords: Biological activity, cytotoxic, antiviral, antiparasitic, nanocapsulation

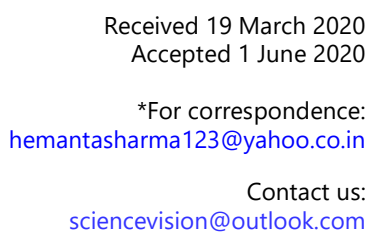

\section{Introduction}

Restoring or rectifying health with medicinal plants is as ancient as mankind itself. Nature is dependably end up being the huge source of medication for the humanity. Recognition of the usage of medicinal plants by humans is the consequences of countless years of hassle against illneses. ${ }^{1}$ On the report of evolving situation made in the scientific field, keen interests have been given on the therapeutic properties of plants because they exhibit relatively less adverse effects and are safe, eco-friendly and locally available. ${ }^{2}$ Plants were strongly believed to have healing power in almost all ancient civilizations. Because Homo sapiens are omnivorous, hence take plants or plant parts as a principle component of diet for their nutritious content and medicinal value. In drug development, either pharmacopoeial, non-pharmacopoeial or synthetic drugs, medicinal plants are considered as rich resources of ingredients and thereby making them the source to upscale supply of different types of medicines. ${ }^{3}$

Some of the drugs obtained from plant are aspirin, atropine, artemisinin, colchicine, digoxin, ephedrine, morphine, physostigmine, pilocarpine, quinine, quinidine, reserpine, taxol, tubocurarine, vincristine, vinblastine, etc. The medicinal value of plants lies in bioactive phytochemical constituents that produce definite physiological action on the human body. Some of the most important bioactive 
phytochemical constituents are alkaloids, essential oils, flavonoids, tannins, terpenoids, saponins, phenolic compounds, etc. ${ }^{4}$

This review covers the major activities of essential oils and problems associated with delivery of essential oil. Possible solutions and delivery strategies of essential oils are also described.

\section{Essential oil}

Essential oils (EOs) are aromatic, concentrated oily liquids obtained from plant organs, i.e. seeds (e.g. Nigella sativa, Anethum graveolens), fruits (e.g. citrus fruits), fruits peel (Citrus japonica), flowers (e.g. Lavandula officinalis, Halimondendron halodendron), roots (e.g. Ballota nigra, Valeria najatamansi, and Zingiber officinale), rhizome (e.g. Z. officinale), buds, twigs, leaves (e.g. Artemisia monosperma, Artemisia douglasiana, Pimenta dioica, and Eucalyptus citriodora) wood or bark (Cordia trichotoma, Cinnamomum cassia).

In sixteenth century, Swiss reformer of medicine Paracelsus von Hohenheim coined the term "essential oil", derived from the term quinta essentia. Essential oils can be defined as either mixtures of fragrant substances or as mixtures of fragrant and odourless substances; they are also termed as volatile or ethereal oils. They are composed mainly of monoterpenes, phenylpropenes, flavonoids and polyunsaturated omega-6-fatty acids. EOs are fat soluble and are small so that they are able to pass across the membranes or the skin and reaches the systemic circulation before being entering the microcirculation. $^{5-9}$

\section{Sources of essential oil}

There are about 3000 different plant species containing EOs have been reported out of which only 300 of them are economically important. EOs are used in the fragrance, food, pharmaceutical, agricultural, and sanitary industries. They are formed through a schizolysigenous process in cluster gland cells and accumulated in secretory cavities, cells, epidermis cells, glandular trichomes of plant organs. ${ }^{6}$ EOs can be extracted by several methods which involve utility of microwaves or liquid carbon dioxide, and predominantly low- or high-pressure distillation engaging heated water or hot steam.

Due to their bactericidal and fungicidal properties, pharmaceutical and food uses are more and more widespread as alternatives to synthetic chemical products. In those cases, extraction by steam distillation or by expression is preferred and for perfume uses, extraction with lipophilic solvents and sometimes with supercritical carbon dioxide is favoured. Thus, the essential oil products differ not only in their chemical profiles and in the number of molecules but also in the stereochemical types of molecules extracted, according to the type of extraction. Depending on the change in climate, soil composition, age, plant organ, assemblage time and vegetative cycle stage, the quality, quantity and composition of the extract varyconsiderably. ${ }^{5}$

\section{Biological activities of essential oil}

Various biological activities of EOs are shown in Figure 1.

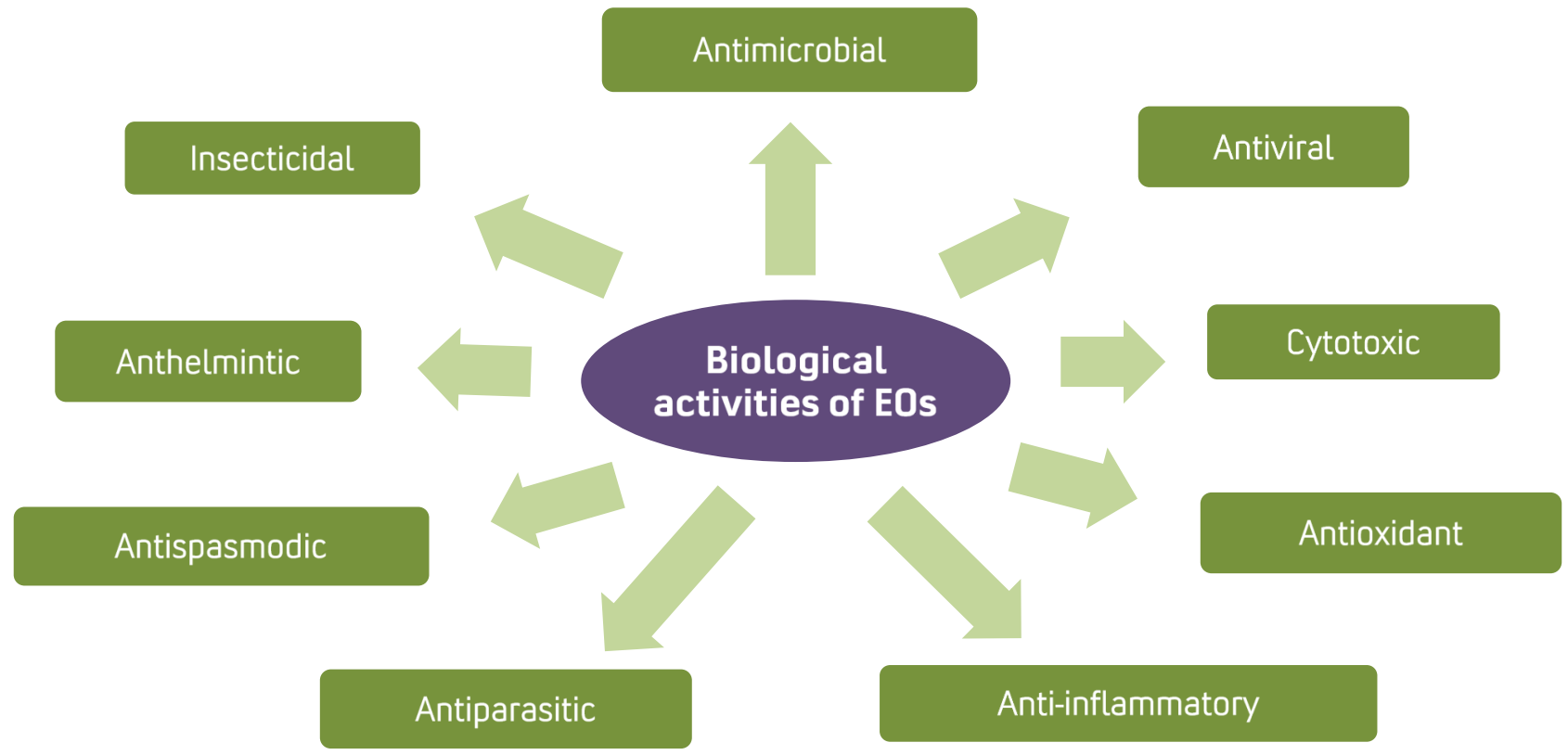

Figure 1 | Major biological activities of essential oils. 
Table 1 | Plants that contain essential oils with antispasmodic activity

\begin{tabular}{|c|c|c|}
\hline Plant containing EO & Mechanism of antispasmodic action* & References \\
\hline Acorus calamus & Inhibition of $\mathrm{Ca}^{2+}$ channels & 13 \\
\hline Anethum graveolens & Inhibition of $\mathrm{Ca}^{2+}$ channels & 14 \\
\hline Artemisia dracunculus & Not found & 15 \\
\hline Carum carvi & Not found & 16,17 \\
\hline Chamomile nobile & Direct smooth muscle relaxation & 18 \\
\hline Chrysactinia mexicana & Inhibition of $\mathrm{Ca}^{2+}$ channels & 19 \\
\hline Citrus aurantifolia & Not found & 20 \\
\hline Citrus aurantium & Not found & 21 \\
\hline Coriandrum sativum & Inhibition of $\mathrm{Ca}^{2+}$ channels & 22 \\
\hline Cymbopogon citratus & Inhibition of $\mathrm{Ca}^{2+}$ channels & 23 \\
\hline Cymbopogon schoenanthus & Not found & 24 \\
\hline Elettaria cardamomum & Inhibition of $\mathrm{Ca}^{2+}$ channels & 25 \\
\hline Ferula heuffelii & Not found & 26 \\
\hline Foeniculum vulgare & Not found & 27 \\
\hline Hofmeisteria schaffneri & Not found & 28 \\
\hline Lippia alba & Reduction of calcium influx, stimulation of NO production & 29 \\
\hline Lippia thymoides & Not found & 30 \\
\hline Matricaria recutita & $\mathrm{K}^{+}$channels activation & 16 \\
\hline Melissa officinalis & Inhibition of $\mathrm{Ca}^{2+}$ channels & 16,31 \\
\hline Mentha spicata & Inhibition of $\mathrm{Ca}^{2+}$ channels & 32 \\
\hline Mentha $x$ villosa & Not found & 33 \\
\hline Ocimum basilicum & Inhibition of $\mathrm{Ca}^{2+}$ channels & 34 \\
\hline Ocimum gratissimum & Not found & 35 \\
\hline Ocimum selloi & Inhibition of $\mathrm{Ca}^{2+}$ channels & 36 \\
\hline Origanum majorana & Inhibition of $\mathrm{Ca}^{2+}$ channels & 37 \\
\hline Plectranthus barbatus & Direct smooth muscle relaxation & 38 \\
\hline Pimpinella anisum & Activation of NO-cGMP pathway & 39 \\
\hline Pistacia integerrima & Inhibition of $\mathrm{Ca}^{2+}$ channels & 11 \\
\hline Rosmarinus officinalis & Inhibition of $\mathrm{Ca}^{2+}$ channels & 40 \\
\hline Salvia officinalis & $\mathrm{K}^{+}$channels activation & 41 \\
\hline Sature jahortensis & Not found & 42 \\
\hline Xylopia frutescens & $\begin{array}{l}\text { Inhibition of } \mathrm{Ca}^{2+} \text { channels; antagonism of histaminergic } \\
\text { receptors }\end{array}$ & 43 \\
\hline Xylopia langsdorfiana & Decrease in cytosolic calcium concentration & 44 \\
\hline
\end{tabular}

\section{Antispasmodic activity}

EOs are found to possess marked antispasmodic property. There is a report on antispasmodic effect of essential oils obtained from several species of aromatic plant along with the mechanistic discussion and composition of the essential oil. ${ }^{10}$ It has been demonstrated that the presence of cymene, borneol, tetrahydrocarvone, 4-carvomenthenol, terpinenol, $\alpha$ terpinene and $\beta$-caryophyllene, levo-bornyl acetate, aromadendrene in the essential oil of Pistacia integerrima, which are responsible for relaxing the isolated ileum and inhibiting the contraction induced by receptor-dependant and independent mechanisms. ${ }^{11}$ Similarly another researcher investigated the effect of essential oil extracted from Croton nepetaefolius on intestinal motility in vivo and on isolated preparations of gastrointestinal smooth muscle and found that it possess a potent modulator of intestinal smooth muscle. ${ }^{12}$ Several studies confirmed the antispasmodic effect of essential oils, as listed in Table 1.

\section{Antimicrobial activity}

It has long been recognised that some EOs have antimicrobial properties, recent enhancement of interest in 'green' consumerism has led to a renewal of scientific interest in these substances. ${ }^{45}$ Some of the essential oils along with the name of microbes 
Table 2 | List of some essential oils along with the microbes they inhibit

\begin{tabular}{|c|c|c|}
\hline EO or component & Microbial species & References \\
\hline Clove oil & $\begin{array}{l}\text { E. coli, S. aureus, A. hydrophila, L. monocytogenes, } \\
\text { Streptococcus thermophilus, Lactobacillus bulgaricus, S. } \\
\text { typhimurium }\end{array}$ & 46,47 \\
\hline Eugenol & L. monocytogenes, A. hydrophila, Microsporum gypseum & 48 \\
\hline Sage oil & B. cereus, S. aureus, S. typhimurium & 47 \\
\hline Oregano oil & $\begin{array}{l}\text { Natural flora, Photobacterium phosphoreum, C. botulinum, L. } \\
\text { monocytogenes, S. enteritidis, E. coli }\end{array}$ & 47 \\
\hline Coriander oil & $\begin{array}{l}\text { A. hydrophila, Salmonella choleraesuis, Streptococcus } \\
\text { haemolyticus, Shigella sonnei, Shigella flexneri, E. coli, } \\
\text { Salmonella choleraesuis, Corynebacterium diphtheria, } \\
\text { Streptococcus haemolyticus, Staphylococcus aureus, Bacillus } \\
\text { subtilis, Pseudomonas aeruginosa, Klebsiella spp., Proteus } \\
\text { vulgaris }\end{array}$ & $47,49,50$ \\
\hline Cinnamon oil & Streptococcus thermophilus, Lactobacillus bulgaricus, E. coli & $47,51,52$ \\
\hline Thyme oil & L. monocytogenes, Pseudomonas putida, E. coli & 47,53 \\
\hline Cilantro oil & L. monocytogenes & 47 \\
\hline Cinnamaldehyde & Pseudomonas putida, Salmonella spp. & 52 \\
\hline Carvacrol & $\begin{array}{l}\text { B. cereus, S. typhimurium, E. coli, L. monocytogenes, Natural } \\
\text { flora }\end{array}$ & 47 \\
\hline Citral & S. typhimurium, L. monocytogenes, S. aureus, E. coli & 47 \\
\hline Geraniol & S. typhimurium, E. coli, L. monocytogenes, & 47 \\
\hline Thymol & $\begin{array}{l}\text { Salmonella spp., Shigella sonnei, S. typhimurium, B. cereus, L. } \\
\text { monocytogenes, S. aureus }\end{array}$ & 47 \\
\hline Ginger essential oil & Mycobacterium spp. & 7 \\
\hline A. Douglasiana leaf oil & $\begin{array}{l}\text { Bacillus cereus, S. aureus, E. coli, P. aeruginosa, Candida } \\
\text { albicans, Aspergillus niger }\end{array}$ & 8 \\
\hline Linalool & Botrytis cinerea & 54 \\
\hline
\end{tabular}

against which they are active are given in Table 2 .

\section{Antiviral activity}

A study reported that $A B 1$ blend $3.52 \%$ of Eucalyptus globules, $3.52 \%$ Cinnamomum zeylanicum, $3.00 \%$ of Rosmarinus officinalis, $1.04 \%$ of Daucus carota, and $88.90 \%$ of Camelina sativa oils) was effective against $\mathrm{H} 1 \mathrm{~N} 1$ and HSV1 viruses. ${ }^{55}$ Another researcher investigated the antiviral effect of $0.5 \%$ of lemon EO, $0.1 \%$ of orange, $0.1 \%$ of grape fruit EOs and $0.05 \%$ of rosemary cineole EO against Hepatovirus $A$ (HAV); and reported that lemon, grapefruit, and rosemary cineole EOs significantly reduced the HAV titers on fruit surface. ${ }^{56}$ In the same way another researcher investigated the in vitro antiviral activity of Melaleuca alternifolia essential oil (TTO) and its main components, terpinen-4-ol, $\alpha$-terpinene, $\gamma$-terpinene, $\rho$-cymene, terpinolene and $\alpha$-terpineol and reported that TTO has an antiviral activity against influenza $A / P R / 8$ virus subtype H1N1. ${ }^{57}$

\section{Antioxidant activity}

A study demonstrated the antioxidant activity of essential oils of Cananga odorata, Boswellia thurifera, Cymbopogon citratus, Marjorana hortensis, Ocimum basilicum, Rosmarinus officinalis, Cinnamomum zeylanicum and Citrus limon in comparison with $\alpha$ tocopherol and butylated hydroxytolune. ${ }^{40}$ There is a report on the free radical scavenging activity and antioxidant potential of EO and methanolic extract of Zanthoxylum alatum in vitro together with its scavenging ability versus DPPH·, mitigating power and chelating capability on $\mathrm{Fe}^{2+}$ ions and found to have efficient activity. ${ }^{58}$ Another study reported that Thymus bovei essential oil contains several volatile bioactive components, especially the oxygenated monoterpenoids, which showed strong antioxidant activity; so could potentially be used as natural preservatives in food and pharmaceutical industries. $^{59}$

\section{Cytotoxic activity}

A study concluded that the lavender (Lavandula angustifolia) oil which contain linalyl acetate and linalool as major constituent are cytotoxic to human skin cells in vitro (endothelial cells and fibroblasts) at a concentration of $0.25 \%(\mathrm{v} / \mathrm{v})$ in all cell types tested (HMEC-1, HNDF and 153BR). ${ }^{60}$ There is a report on 
the cytotoxic effect of the essential oil from the dried leaves of Lippia citriodora against the P815 murine mastocytoma cell line using the MTT assay and found that the EO can induce apoptosis against P815 tumor cell line. ${ }^{61}$ An evaluation of the antitumor activity of essential oil of Mentha crispa found to be cytotoxic against U87 MG cells, with $I_{50}$ values of $16.263 .^{62}$ It has been reported that the essential oil of Stachys koelzii possess acceptable cytotoxic effects of against HeLa cell line, lower side effects on normal healthy cell lines. ${ }^{63}$

\section{Anti-inflammatory activity}

There is a reported on the anti-inflammatory activity of Cinnamonmum zeylanicum bark essential oil (CBEO) on several inflammatory biomarkers which include vascular cell adhesion molecule-1, intercellular cell adhesion molecule-1, monocyte chemoattractant protein-1, interferon gamma induced protein 10, interferon-inducible T-cell alpha chemoattractant, and monokine induced by gamma interferon. CBEO could also modulate global gene expression and can alter signalling pathways, many of which are important in inflammation, tissue remodeling, and cancer biology. ${ }^{64}$ Another study investigated the anti-inflammatory properties of compounds found in the lavender essential oil (LEO) using two models of acute inflammation: carrageenan-induced pleurisy and croton oilinduced ear edema and the results found to be efficacious. $^{65}$

The chemical composition and anti-inflammatory activity of essential oil of Jatropha curcas has been studied and found that the oil contain $35.8 \%$ of neophytadiene, $23.1 \%$ of phytol, $12.7 \%$ of transpinane, $12.3 \%$ of $6,10,14$-trimethyl-2-pentadecanone and $11.2 \%$ of citronellylpropanoate. The antiinflammatory activity of oil was showed significant inhibition at a dose of $2 \%, v / v^{66}$ Similarly, another researcher investigated the anti-inflammatory, antimicrobial, antiviral, antioxidant properties of Eugenia caryophyllata essential oil and found to have significant effect on the increased production of several pro-inflammatory biomarkers like vascular cell adhesion molecule-1 (VCAM-1), interferon cinduced protein 10 (IP-10), interferon-inducible Tcell a chemoattractant (I-TAC), and monokine induced by $\mathrm{c}$ interferon (MIG). CEO also significantly inhibited tissue remodelling protein molecules, namely, collagen-I, collagen-III, macrophage colonystimulating factor (M-CSF), and tissue inhibitor of metalloproteinase 2 (TIMP-2). ${ }^{67}$

\section{Antiparasitic activity}

There is an investigation on the antiparasitic activity of the essential oil from the fruits of Piper tuberculatum, against lines of Leishmania infantum (MHOM/ES/92/BCN83), Leishmania braziliensis
(MHOM/CO/88/UA301) and Trypanosoma cruzi (LCB5 clone) and reported that the essential oil possess good antiparasitic potential. ${ }^{68} \mathrm{~A}$ researcher assessed the in vivo and in vitro antiparasitic activity of the essential oil of Lippia sidoides and blood and histological alterations in Colossoma macropomum (tambaqui) and found positive results. ${ }^{69}$ It has been demonstrated that the antiparasitic activity of the essential oil obtained from Phania matricarioides against $T$. cruzi; and founded high safety of the EO when compared in mammalian cells based on the high selectivity index. ${ }^{70}$

\section{Anthelmintic activity}

There is a report on the in vitro anthelmintic activity of essential oil from Brazilian red propolis (EOP) against larvae of Toxocara cati and $600 \mathrm{~g} / \mathrm{mL}$ of the EOP showed larvicidal activity after exposure for $48 \mathrm{hr}^{71}$ Another study reported that the anthelmintic effects of the essential oil of Foeniculum vulgare showed moderate in vitro schistosomicidal activity against Schistosoma mansoni. ${ }^{72}$ Similarly, another researcher studied the Thymus bovei essential oil and revealed that the essential oil showed powerful anthelmintic effect even greater than the effect of the control drug piperazine citrate. $^{59}$

\section{Insecticidal activity}

The essential oil extracted from garlic and its constituents like diallyldisulfide, dimethyl trisulfide, diallyltetrasulfide, diallylsulfide, and 3-vinyl-[4H]-1,2dithiin were found to be toxic to Tenebrio molitor Linnaeus larva, followed by pupa and adult. ${ }^{73}$ It has been reported that the essential oil extracted from rhizome of Cheilocostus speciosus have insecticidal activity against the old-world bollworm, Helicoverpa armigera. $^{74}$ Another study demonstrated the insecticidal activity of essential oil, active constituents obtained from Satureja hortensis against Acrobasis advenella, and found to be useful. $^{75}$

\section{Route of delivery of essential oils}

\section{External application}

\section{Inhalation}

The absorption of essential oils in the bloodstream is intervened on two fronts via the skin respiratory system. Aromatherapy also referred to as "essential oil therapy" is a complimentary health approach that works by stimulating smell receptors in the nose and obtain an outcome in seconds. Owing to its preferential method, oil diffusion into the air takes place by utility of heat, utility of water 
and atomization. ${ }^{76}$ EOs have been broadly exploited in the treatment of ailments such as ameliorating cognitive efficiency, relieve pain, body relaxation and much more other psychological and physical conditions. $^{77}$ EOs from herbs possess antidepressant potential that can govern the brain function in many ways. Their fast-onset effect is based on the aromatic odor that can lightly activate the olfactory nerves. Due to their volatility in nature, they are considered convenient for nasal-brain targeted and inhalation delivery. $^{78}$

\section{Mouthwashes}

Several studies have shown that self-performed brushing alone is not efficacious for the withdrawal of plaque and demand improvement. ${ }^{79}$ With this in mind, antimicrobial mouthrinses (containing essential oils, cetylpyridinium chloride, or chlorhexidine) in combination with brushing are employed and found to have better impact in the removal and disruption of the amassed plaque layers and effective against gingivitis. ${ }^{80,81}$ Several ingredients such as water, alcohol, buffering agents, surfactants and flavouring agents are used in the manufacturing of mouthrinses. Alcohol is often used as a preservative and solubilizer of EOs to maintain bioavailability. However, the use of alcohol have been limited due to some problems encountered as mentioned. $^{82}$ In view of this, an alcohol-free EO mouth rinse (AFM) was developed and evaluated in vitro and in vivo and demonstrated its efficacy in reducing plaque and gingivitis in clinical trials. ${ }^{83,8}$

\section{Topical or transdermal}

Topical or transdermal route of application is considered dependable for the delivery of EOs. These oils due to their volatility are able to infiltrate the skin, also, improve the infiltration of several drugs therefore topical formulation towards the lower skin layers thereby involves various mechanism of action: (i) conformational modification due to interaction with intercellular domain of protein, (ii) disintegrating the profoundly ordered intercellular lipid structure enclosed by corneocytes in stratum corneum, (iii) partitioning of the drug is enhanced. ${ }^{85,86}$ Even through physical techniques such as phase separation, fluidization, extraction and increased disorder, EOs can enhance the transmission of small drug compounds. Penetration of EOs through the skin membrane and then to the blood stream is problematic, they get readily eliminated with faces or urine from the body. Because of their better safety profile, the use of EOs has gained attention. ${ }^{86,87} 90 \%$ of EOs are delivered through dermal or transdermal route, which trait to non-invasive, patient's compliance and reduction of adverse effect. ${ }^{88}$

\section{Internal application}

\section{Oral}

Generally, EOs are initially diluted with olive oil, milk and soya milk before they are orally administered. They are absorbed in the buccal mucosa at a rate of 3-9 times higher compared to the $\mathrm{Gl}$ system absorption rate, also, having the capability of 4,000 times higher permeation rate. This makes the delivery of essential oils more efficient and reliable indicating that the ingested oils rapidly penetrate into the blood-stream after administration. ${ }^{89}$ In a study on zedoary turmeric oil for oral delivery was prepared and reported improved aqueous stabilization, dispersity and oral bioavailability which has been carried out in rats. ${ }^{90} \mathrm{~A}$ study was performed on Croton cajucara oil where the formulation was orally administered in rats and assessed. The author concluded that the essential oil exhibited low toxicity in mice and offered gastroprotective benefits. $^{91}$

\section{Problems in delivery of essential oils}

The use of EOs in their free form reduces their effectiveness because they easily get volatilized and decomposed when exposed to oxygen, light, humidity, heat or irradiation. ${ }^{53}$ Essential oils are unstable and possess poor water solubility. The components of EOs that belong to same chemical group are structurally similar which results easy inter conversion of the component, enzymatically or chemically triggering oxidation, isomerization, cyclization, or dehydrogenation reactions. ${ }^{92}$ These changes can occur during handling of the oil or during distillation, processing and storage of the plant material. Again some oil, like bergamot oil can cause photosensitization reaction and can even induce malignant change.

Sometimes aromatherapy can cause skin irritation, especially if the oils are concentrated. Even applying the concentrated oil topically, in excess amount to broken or on large surface of the skin can cause serious side effects as they undergo systemic absorption. Storing EO for long duration of time may result change in organoleptic characteristics along with change in viscosity and oxidation of terpenoids compounds results hypersensitivity reaction like allergic contact dermatitis. ${ }^{92}$

\section{Solutions suggested}

An alternative to solve the problems related to stability, solubility, bioavailability of oil would be on their micro or nanoformulation, seeking protection against instability, decomposition and improves therapeutic efficacy. To preserve oil through encapsulation various colloidal systems can be used 


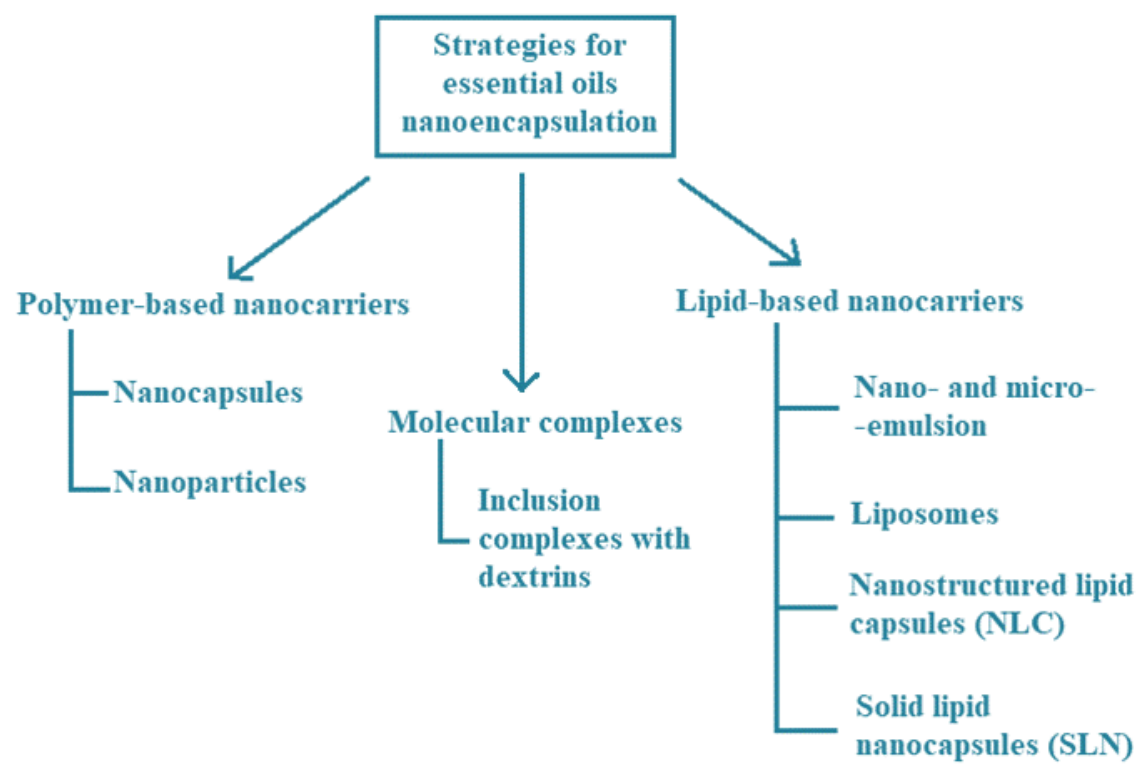

Figure 2 | Strategies involved in delivery of essential oils.

such as nanoemulsions, liposomes, microemulsion and microcapsules, etc. The proposed strategies to overcome the shortcoming of essential oils delivery are given in Figure 2.

\section{Polymer-based nanocarriers}

\section{Nanocapsules}

Nanocapsules are vesicular systems consist of nanoscale shell which is made from a nontoxic polymer and a space/core which can be aqueous or oily where the desired substance is confined. The active ingredient incorporated inside the core can be solid or liquid. If the active substance is lipophilic then it may get solubilised in the core cavity or may get adsorbed on the polymeric shell depending on its solubility. ${ }^{93}$ Nanocapsules are submicroscopic colloidal drug carrier systems and its sizes range from 5 to $1000 \mathrm{~nm}$, but usually the accepted range is in between $100-500 \mathrm{~nm} .{ }^{94}$ They can be prepared by various methods namely, nanoprecipitation, emulsion/solvent diffusion, double emulsification polymer coating, salting out, dialysis, solvent evaporation, interfacial polymerization, supercritical fluid technology. They provide good shielding environment to peptides, hormones, proteins, enzymes, drug, metabolites, or molecules against biological and chemical degradation; they can also delay the release of active ingredients and possess site specificity, therefore they attained great interest in drug delivery system. ${ }^{94}$ The advantages of nanocapsules include, higher encapsulation efficiency, specific absorption mechanism across the GIT, sustained release, biocompatibility, biodegradability, membrane efflux transporter inhibition, targeting potential and oral deliver ability. ${ }^{95}$ Considering these advantages, these systems can actually provide a novel approach for delivering essential oil and overcoming its limitations.

The important ingredients used in nanocapsules formulation for delivery of oil are given in Table 3 . There is a report on nanocapsules as a system for carrier of vitamin E, prepared by nanoprecipitation method for laboratory scale and pilot-scale. This method provided nanocapsules with mean diameter of 165 and $172 \mathrm{~nm}$, respectively and with high entrapment efficiency i.e. of $98 \%$ and $97 \%$ respectively. ${ }^{96}$ It has been demonstrated that chitosan-alginate nanocapsules were developed for encapsulation of essential oil and found that the formulated nanocapsules were hemo-compatible and can be used in biomedical and pharmaceutical field. ${ }^{97}$

\section{Nanoparticles}

Nanoparticles are sub-nanosized, solid, colloidal drug delivery systems with particle size ranges from 10 to $<1000 \mathrm{~nm},{ }^{98,99}$ Nanoparticles can be developed into better systems by manipulating the size, surface characteristics and material employed, which improve therapeutic efficiency and stealth property. Again this system can deliver the drug in controlled manner and to the targeted site, which decrease the dose and dosing frequency thereby reduce toxicity and patience incompliance. ${ }^{99}$ Nanoparticles can break the damaged or inflamed tissue and this penetration can occur passively or actively. In passive targeting, no ligand is used and targeting is attained when nanoparticles when nanoparticles loaded drug 
Table 3 | Components for formulation of nanocapsules

\begin{tabular}{|c|c|}
\hline Component & Examples \\
\hline Oils & Vegetable oil, mineral oil, etc. \\
\hline Surfactant & $\begin{array}{l}\text { Natural lecithins from plant or animal source, laryl sulphate, [poly (oxyethylene) poly (propylene) } \\
\text { glycol] }\end{array}$ \\
\hline Cosurfactant & Ethanol, glycerine, PEG300, PEG400, polyene glycol, poloxamer \\
\hline Polymer & $\begin{array}{l}\text { Polylactic acid, polyglycolic acid, polylactic-co-glycolic acid, hydroxypropylmethyl cellulose, } \\
\text { chitosan }\end{array}$ \\
\hline
\end{tabular}

reaches the target through the leaky nature of the vessel. However, in active targeting, the carrier system is conjugated to a tissue or cell specific receptor using ligand. For efficient targeted drug delivery, various materials can be used that modify the physiochemical properties which increase their loading capacity, stability and intra cellular delivery. ${ }^{98,100}$

Nanoparticles can also protect the essential oil from oxidation or evaporation, photo or thermal degradation which helps to extend the shelf life and therapeutic activity of the final product. ${ }^{101}$ These features can be considered for overcoming essential oils delivery. Ferreira et al. used chitosan nanoparticles for encapsulating the EO of Siparuna guianensis to prolong its mosquitocidal activity. This study indicates that chitosan nanoparticles are suitable system for preserving the properties of EO of Siparuna guianensis essential oil in an aqueous medium and protects it from degradation. ${ }^{102}$ In another study nanoparticles loaded with eucalyptus or rosemary essential oils were developed and evaluated their wound healing and antimicrobial property; and proved its efficacy and safety in in vivo rat model. ${ }^{103}$

\section{Molecular complexes}

A molecular complex generally attribute to the physical union between a host and a guest molecule. In order to increase solubility and chemical stability of the active ingredient a simple strategy is to physically complex them with other molecule. For EOs the complexes are reported with cyclodextrins. ${ }^{104}$

\section{Inclusion complexes with dextrins}

Cyclodextrins (CD) are a family of cyclic oligosaccharides, consisting of five or more glucopyranosyl units joined together by $\alpha-1,4-$ glycosidic bonds. They are also known as cycloamyloses, cyclomaltoses and Schardinger dextrins. ${ }^{105}$ They consist of hydrophobic core and hydrophilic exterior, so hydrophobic drug can easily encapsulated into the core of cyclodextrins with non -covalent interaction which results in alter physical and chemical proportions and thus increase the aqueous solubility and chemical stability of the guest molecule. ${ }^{106}$ To prevent evaporation of the volatile compound, allylisothiocyanate present in 'wasabi', a Japanese spice, an inclusion complex is made with cyclodextrin. In nanodelivery, cyclodextrins facilitate cellular uptake and thereby reduce toxicity. Due to their high stability and nontoxic nature they have attractive pharmaceutical applications and $\beta$ forms of cyclodextrins are widely used as they improve oral bioavailability. Therefore their complexes with essential oils enhance the water solubility of the EOs; and the chemical modifications in both primary and secondary substituent further improve the solubility and biodegradability with reduced toxicity. ${ }^{107}$

The advantages of $C D$ include protection of the guest molecule against light, oxidation, thermal decomposition, evaporation or sublimation, GIT irritation, drug-drug interactions and elimination of undesired taste/odour, hygroscopicity. ${ }^{108}$ These features of $C D$ carrier system can overcome the limitations related to essential oil delivery. In a study, the physical and chemical condition of the $\beta$ cyclodextrins complexation reaction for several types of essential oils along with their release characteristic were investigated and found that encapsulation of EOs using $\beta$-cyclodextrin promote their therapeutic uses. ${ }^{109}$ Encapsulation of the EO of clove in hydroxypropyl beta-cyclodextrin (CEO-HPBCD) inclusion complexes in 1:1 molecular ratio using Kneading method was performed in an experiment. The study revealed that this system increased the total phenolic content of free EO as well as total phenolic content of particles and also prolongs the shelf life of the encapsulated EO. ${ }^{110}$

\section{Lipid-based nanocarriers}

\section{Nano- and microemulsions}

Nanoemulsions (NE) and microemulsions (ME) are transparent, monophasic, optically isotropic colloidal dispersions consists of two immiscible phases, oil and aqueous phase, along with surfactant and co-surfactant. The difference between NE and $\mathrm{ME}$ are that in case of NE the colloidal dispersion is kinetically stable with droplet sizes less than $100 \mathrm{~nm}$ while in ME the colloidal dispersion is thermodynamically stable with droplet sizes in the 
Table 4 | Comparison between nanoemulsions and microemulsions

\begin{tabular}{lll}
\hline Properties/Parameters & Nanoemulsions & Microemulsions \\
\hline Physical description & Colloidal dispersion & Colloidal dispersion \\
\hline Particle size & $<100 \mathrm{~nm}$ & $10-00 \mathrm{~nm}$ \\
\hline Polydispersity & Low & Low \\
\hline Thermodynamic stability & Unstable & Stable \\
\hline Kinetic stability & Stable & Unstable \\
\hline Preparation & Low/high energy & Low energy \\
\hline Composition: surfactant to oil ratio & Moderate & Low \\
\hline Loading capacity & High & Moderate \\
\hline Physical appearance & Transparent & Transparent \\
\hline
\end{tabular}

range $10-100 \mathrm{~nm} .{ }^{111}$ The similarities and dissimilarities between NE and ME are summarized in Table 4.

Among $\mathrm{NE}$ and $\mathrm{ME}, \mathrm{NE}$ are found to be more efficient for delivery of essential so, it is described further.

NE can be prepared using two preparation methods, viz. low-energy and high-energy emulsification method. The high energy emulsification method includes high-pressure homogenization, ultrasonication and membrane emulsification. The low energy emulsification method includes microfluidization, emulsion inversion point, phase transition and phase-inversion temperature method. The advantages of NE include increased rate of absorption of drug, increased drug loading, enhanced bioavailability, controlled/ sustained release of drug and targeted drug delivery.

Both lipophilic and lipophobic drugs can be formulated in NE but encapsulating lipophilic drug are found to be more effective, as in this system the droplet size of the lipophilic molecule get decrease thereby enhances their solubility, stability and subsequently the biological activity. This system is nontoxic, non-irritant because the components used in this system are generally regarded as safe and exclude the requirement of harmful co-solvents, so, they can be used for both parenteral and nonparenteral route. NE can also protect the drugs from oxidation and hydrolysis process. It can be formulated in variety of formulation such as foams, liquids, sprays and creams. Their long-term stability, ease of preparation (spontaneous emulsification), high encapsulation efficiency, high bioavailability, protection from enzymatic degradation and high solubilisation of drug molecules makes them promising as a drug delivery tool for essential oil. ${ }^{112}$ The ingredients required for formulation of nanoemulsions are given in Table 5. ${ }^{113,114}$

There is a report where nanoemulsions were formulated containing oil of Cinnamonum zeylanicum with droplet diameter of $65 \mathrm{~nm}$ using Tween 80 and water by ultrasonic emulsification for 30min which demonstrated bactericidal activity against food-brone pathogen Bacillus cereus. The study illustrated that emulsification time, oilsurfactant mixing ratio and surfactant concentration had significant effect on nanoemulsion droplet diameter and its stability. ${ }^{115}$ Another researcher discussed nanosystems with utility in skin delivery and focuses on the composition and characterization of microemulsion and nanoemulsion for topical and

Table 5 | Components of nanoemulsions.

\begin{tabular}{ll}
\hline Component & Examples \\
\hline Oils & Castor oil, corn oil, coconut oil, evening primrose oil, linseed oil, mineral oil, olive oil. etc \\
\hline Emulgent & Natural lecithins from plant or animal source, phospholipids, castor oil \\
\hline Surfactant & Polysorbate20, Polysorbate80, Polyoxy60, castor oil, Sorbitanmonooleate \\
\hline Cosurfactant & Ethanol, glycerine, PEG300, PEG400, Polyene glycol, Poloxamer \\
\hline $\begin{array}{l}\text { Tonicity } \\
\text { modifiers }\end{array}$ & Glycerol, sorbitol, and xylitol \\
\hline Additives & $\begin{array}{l}\text { Propylene glycol, lower alcohol (ethanol), propylene glycol, 1, 3-butylenes glycol, sugars such as } \\
\text { butylene glycol, sugars such as glucose, sucrose, fructose, and maltose }\end{array}$ \\
\hline Antioxidants & Ascorbic acid and tocopherol \\
\hline
\end{tabular}


transdermal delivery. ${ }^{116}$ Similarly, another researcher prepared Plai (Zingiber cassumunar Roxb.) nanoemulsions under oil-in-water emulsion system by high pressure homogenization and obtained that an optimal surfactant component in formulation for fabricate Plainanoemulsion with the small droplet size and had impact in long lasting stability. ${ }^{117}$

\section{Liposomes}

Liposomes are considered among the finest colloidal drug delivery systems which have are developed for delivering drug to a specific site in the body as early as $1970 .^{118}$ Liposomes are enclosed spherical vesicles, organized in one or several concentric phospholipidic bilayers with an internal aqueous phase and their diameter ranges from 80 $\mathrm{nm}$ to $100 \mu \mathrm{m}$. They are suitable templates for drug delivery as they provide promising drug carriers due to their capability of cutaneous targeting and slow release of the drug. ${ }^{119}$ They are also suitable for encapsulating natural compounds like essential oil, which improve its solubility and chemical stability. ${ }^{120}$ They prevent the encapsulated bioactive compounds from degradation and increase the solubility of lipophilic compounds. The advantages of liposomal encapsulation includes improvement of therapeutic activity and safety, local delivery of medicament at the site of action, controlled and sustained drug delivery, increased bioavailability as their surface can be modified to alter their biodistribution and pharmacokinetics. ${ }^{121}$ Liposomes can encapsulated with hydrophilic, hydrophobic and amphiphilic substances. The structural components of liposomes are phospholipids and cholesterol. Phospholipids can be natural and synthetic and the most commonly used phospholipid is known as lecithin; it is amphipathic. Cholesterol increases the stability of the lipid vesicles by modulating the fluidity of the lipid bilayer. ${ }^{122}$

An investigation on the effects of core-wall ratio on the stability and antibacterial activity during storage of the encapsulated cinnamaldehyde by liposomes was performed and found that liposomeencapsulated cinnamaldehyde might still inhibit bacteria by destroying cell membrane integrity after storage and the persistence was more efficient than that of pure cinnamaldehyde. Therefore, liposomes could improve the stability and long-term antibacterial activity of cinnaldehyde. ${ }^{123}$ There is a report where nanovesicles were developed by loading essential oils of Salvia triloba and Rosmarinus officinalis. Liposomes loaded with 100 $\mu \mathrm{L} / \mathrm{mL}$ of $\mathrm{EO}$, were optimised for their size, polydispersity index, ל-potential, recovery, encapsulation efficiency (EE \%), release property and morphology. The prepared liposomes were stable over one month period if stored at $4^{\circ} \mathrm{C}$ and possessed significant antioxidant, anti-inflammatory and antibacterial activities. The findings suggest that these formulations can decrease the volatility of EOs, optimise their biological properties and defeat antimicrobial infections. ${ }^{124}$ It has been established that phospholipid vesicle from natural soybean would increase the durability of clove essential oil and eugenol which is its main constituent. The study was performed and discovered that liposomes manifested spherical shaped and nanometre coligolamellar vesicles thereby preventing eugenol from deterioration influenced by UV exposure and also conserved the DPPH-scavenging activity of free eugenol and serve as an apt system for encapsulating the components of unstable volatile essential oil. ${ }^{125}$

\section{Nanostructured lipid capsules}

In 1990, nanostructured lipid capsules (NLC) were first introduced as a carrier systems. ${ }^{126}$ They are colloidal drug delivery systems consisting of a fluid lipid phase enclosed into a solid lipid matrix or confined at the surface of solid matrix and the surfactant layer. In these systems both hydrophilic and lipophilic drug can be used. ${ }^{127}$ The structural arrangement of the lipids provides higher drug loading capacity. The spatial structure of the lipids allows greater drug loading and better stability compared to SLN. These carrier systems can improve the stability as well as bioavailability of the active compounds and they are known to possess excellent

Table 6 | Components used for formulation of NLC

\begin{tabular}{|c|c|}
\hline Component & Examples \\
\hline Liquid lipids & 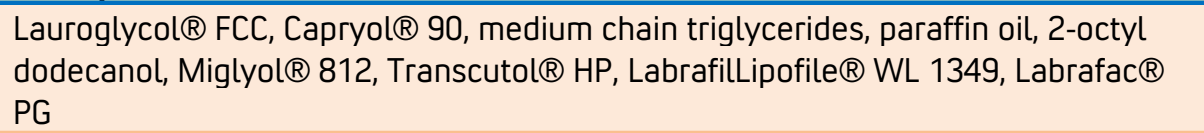 \\
\hline Hydrophilic emulsifiers & $\begin{array}{l}\text { Polyvinyl alcohol, Solutol }(\text { HS15, polyglycerol methyl glucose distearatePluronic } \AA \\
\text { F68 (poloxamer 188), Pluronic } ₫ \text { F127, Tween } 20 \text {, Tween } 40 \text {, Tween } 80\end{array}$ \\
\hline Lipophilic emulsifiers & Span 40, Span 60, Myverol $(18-04 K$, Span 20 \\
\hline Amphiphilic emulsifiers & $\begin{array}{l}\text { Phosphatidylcholines, phosphatidylethanolamines, Gelucire }{ }^{\circledR} 50 / 13 \text {, egg lecithin, } \\
\text { soya lecithin }\end{array}$ \\
\hline
\end{tabular}


biocompatibility. ${ }^{128,129}$ NLC are easier to scale-up, sterilize, validate and approval from regulatory bodies accessible, they also provide controlled and targeted delivery of active constituent. ${ }^{130}$ The ingredients used in this system are mentioned in Table 6.

\section{Solid lipid nanocapsules}

Solid lipid nanoparticles (SLNs) is nano-dispersion and prepared using lipids that are solid at body or room temperature. The lipid component may contain different varieties of lipid and lipid-like molecules, viz. triacylglycerols or waxes. ${ }^{131}$ SLN can increase the permeation of the active compounds as well enhance the contact time which hydrates the skin forming an occlusive barrier, so, these systems mainly used to load hydrophobic compounds like vitamin $A, E$ and coenzyme $Q$ that increase its stability and reduces its degradation by light and oxygen. The size of these systems varies from $50 \mathrm{~nm}$ to $1 \mu \mathrm{m}$ and the active compounds get solubilised easily inside the core part or outside it. ${ }^{132}$ The advantages of these carrier system includes protection against chemical and physical degradation, sustained/controlled release, improve stability, immobilisation of the active compound and suitable for delivery of lipophilic substances. ${ }^{133}$ Hence, it serves the purpose of overcoming the problems of EOs delivery.

\section{Conclusion}

Essential oils possesses important volatile compounds with diverse bioactivities including antimicrobial, antispasmodic, antioxidant, antiviral, anti-inflammatory, anthelmintic, insecticidal, antiparasitic, cytotoxic activity. However, the free form of the EO is prone to physical and chemical decomposition along with poor water solubility, low stability, bioavailability that limits their uses in medicines. Therefore, when EOs are delivered in the form of nano-encapsulation provides promising strategies to overcome the shortcoming of EOs. They will enhance various physiochemical and physiological properties of the EOs and thereby lower their dose, improve safety and therapeutic activity.

\section{Conflict of interest}

The authors do not have any conflict of interest.

\section{References}

1. Petrovska, B.B. (2012). Historical review of medicinal plants' usage. Pharmacognosy Reviews, 11, 1-5. DOI: https://doi.org/ 10.4103/09737847.95849 .
2. Chouhan. S., Sharma, K., Guleria, S. (2017). Antimicrobial activity of some essential oilspresent status and future perspectives. Medicines, 4, 1-21. DOI: https://doi.org/10.3390/ medicines4030058.

3. Sukanya, S.L., Sudisha, J., Hariprasad, P., Prakash, S.R. (2009). Antimicrobial activity of leaf extracts of Indian medicinal plants against clinical and phytopathogenic bacteria. African Journal of Biotechnology, 8, 6677-6682. DOI: https:// doi.org/10.4314/ajb.v8i23.66376.

4. Ullah, N., Zahoor, M., Farhat, A. (2014). A review on general introduction to medicinal plants, its phytochemicals and role of heavy metal and inorganic constituents. Life Science Journal, 11, 520527.

5. Bakkali, F., Idaomar, M. (2008). Biological effects of essential oils - A review. Food and Chemical Toxicology, 46, 446-475. DOI: https:// doi.org/10.1016/j.fct.2007.09.106.

6. Liu, X., Liu, B., Jiang, D., Zhu, S., Shen, W. (2019). The accumulation and composition of essential oil in kumquat peel. Scientia Horticulturae, 252, 121129. DOI: https://doi.org/ 10.1016/ j.scienta.2019.03.042.

7. Baldin, V.P., Bertin de Lima Scodro, R., Mariano Fernandez, C.M., Ieque, A.L., Caleffi-Ferracioli, K.R., Dias Siqueira, V.L., de Almeida, A.L., Gonçalves, J.E., Garcia Cortez, D.A., Cardoso, R.F. (2019). Ginger essential oil and fractions against Mycobacterium spp. Journal of Ethnopharmacology, 244, 95-112. DOI: https://doi.org/ 10.1016/ j.jep.2019.112095.

8. Setzer, W.N., Vogler, B., Schmidt, J.M., Leahy, J.G., Rives, R. (2004). Antimicrobial activity of Artemisia douglasiana leaf essential oil. Fitoterapia, 75, 192200. DOI: https://doi.org/ 10.1016/ j.fitote.2003.12.019.

9. Dhakad, A.K., Pandey, V.V, Rawat, J.M. (2018). Biological, medicinal and toxicological significance of the eucalyptus leaf oil: a review. Science of Food and Agriculture, 98, 833-848. DOI: https://doi.org/ 10.1002/jsfa.8600.

10. Heghes, S.C., Vostinaru, O., Rus, L.M., Mogosan, C., Iuga, C.A., Filip, L. (2019). Antispasmodic effect of essential oils and their constituents: A review. Molecules, 24, 1-29. DOI: https:// doi.org/10.3390/molecules24091675_rfseq1.

11. Shirole, R.L., Shirole, N.L., Saraf, M.N. (2015). In vitro relaxant and spasmolytic effects of essential oil of Pistacia integerrima Stewart ex Brandis Galls. Journal of Ethnopharmacology, 168, 61-65. DOI: 
https://doi.org/ 10.1016/j.jep.2015.02.001.

12. Criddle, D.N., Tavares, R.A., Melo, E.M., Ticiana, L., Magalha, P.J.C. (1998). Intestinal myorelaxant and antispasmodic effects of the essential oil of Croton nepetaefolius and its constituents cineole, methyl-eugenol and terpineol. Phytotherapy Research, 12, 172-177. DOI: https://doi.org/10.1002/ sici10099.

13. Gilani, A.H., Shah, A.J., Ahmad, M., Shaheen, F. (2006). Antispasmodic effect of Acorus calamus Linn. is mediated through calcium channel blockade. Phytotherapy Research, 20, 1080-1084. DOI: https://doi.org/10.1002/ptr.2000.

14. Naseri, M.K.G., Heidari, A. (2007). Antispasmodic Effect of Anethum graveolens fruit extract on rat ileum. Inernational Journal of Pharmacology, 3, 260264. DOI: https://doi.org/10.3923/ijp.2007.260.264.

15. Jalilzadeh-Amin, G., Maham, M., Dalir-Naghadeh, B., Kheiri, F. (2012). In vitro effects of Artemisia dracunculus essential oil on ruminal and abomasal smooth muscle in sheep. Comparative Clinical Pathology, 21, 673-680. DOI: https:// doi.org/10.1007/s00580-010-1155-6.

16. Heinle, H., Hagelauer, D., Pascht, U., Kelber, O., Weiser, D. (2006). Intestinal spasmolytic effects of STW 5 (Iberogast ${ }^{\circledR}$ ) and its components. Phytomedicine, 13,75-79. DOI: https:// doi.org/10.1016/j.phymed.2006.03.013.

17. Al-Essa, M.K., Shafagoj, Y.A., Mohammed, F.I., Afifi, F.U. (2010). Relaxant effect of ethanol extract of Carum carvi on dispersed intestinal smooth muscle cells of the guinea pig. Pharmaceutical Biology, 48, 76-80, DOI: https:// doi.org/10.3109/13880200903046161.

18. Mehmood, M.H., Munir, S., Khalid, U.A., Asrar, M., Gilani, A.H. (2015). Antidiarrhoeal, antisecretory and antispasmodic activities of Matricaria chamomilla are mediated predominantly through $\mathrm{K}+$-channels activation. BMC Complementary Alternative Medicines, 15, 1-9. DOI: https://doi.org/10.1186/s12906-015-0595-6.

19. Zavala-Mendoza, D., Grasa, L., Zavala-Sanchez, M.A., Pérez-Gutierrez, S., Murillo, M.D. (2016). Antispasmodic effects and action mechanism of essential oil of Chrysactinia mexicana A. Gray on rabbit ileum. Molecules, 21, 1-36, DOI: https:// doi.org/10.3390/molecules21060783.

20. Spadaro, F., Costa, R., Circosta, C., Occhiuto, F. (2012). Volatile composition and biological activity of key lime Citrus aurantifolia essential oil. Natural Product Communications, 7, 1523-1526. DOI: https:// doi.org/10.1177/1934578x1200701128.
21. Sánchez-Recillas, A., Arroyo-Herrera, A.L., Araujo -León, J.A., Hernández Núñez, E., Ortiz Andrade, R. (2017). Spasmolytic and antibacterial activity of two Citrus sinensis Osbeck varieties cultivated in Mexico. Evidence-based Complementary and Alternative Medicines, 2017, 1-7. DOI: https:// doi.org/10.1155/2017/3960837.

22. Jabeen, Q., Bashir, S., Lyoussi, B., Gilani, A.H. (2009). Coriander fruit exhibits gut modulatory, blood pressure lowering and diuretic activities. Journal of Ethnopharmacology, 122, 123-130. DOI: https://doi.org/10.1016/j.jep.2008.12.016.

23. Devi, R.C., Sim, S.M., Ismail, R. (2011). Spasmolytic effect of citral and extracts of Cymbopogon citratus on isolated rabbit ileum. Journal of Smooth Muscle Research, 47,143-156. DOI: https://doi.org/10.1540/jsmr.47.143.

24. Pavlović, I., Omar, E., Drobac, M., Radenković, M., Branković, S., Kovačević, N. (2017). Chemical composition and spasmolytic activity of Cymbopogon schoenanthus (L.) Spreng. (Poaceae) essential oil from Sudan. Archives of Biological Sciences, 69, 409-415. DOI: https://doi.org/10.2298/ ABS160506113P.

25. Gilani, A.H., Jabeen, Q., Khan, A., Shah, A.J. (2007). Gut modulatory, blood pressure lowering, diuretic and sedative activities of cardamom. Journal of Ethnopharmacology, 115, 463-472. DOI: https://doi.org/10.1016/j.jep.2007.10.015.

26. Pavlović, I., Petrović, S., Radenković, M., Milenković, M., Couladis, M., Branković, S., Drobac, M.P., Niketić, M. (2012). Composition, antimicrobial, antiradical and spasmolytic activity of Ferula heuffelii Griseb. ex Heuffel (Apiaceae) essential oil. Food Chemistry, 130, 310-315. DOI: https://doi.org/10.1016/j.foodchem.2011.07.043.

27. Ostad, S.N., Soodi, M., Shariffzadeh, M., Khorshidi, N., Marzban, H. (2001). The effect of fennel essential oil on uterine contraction as a model for dysmenorrhea, pharmacology and toxicology study Journal of Ethnopharmacology, 76, 299-304. DOI: https://doi.org/10.1016/S0378-8741 (01)00249-5.

28. Pérez-Vásquez, A., Ángeles-López, G., RiveroCruz, I., Flores-Bocanegra, L., Linares, E., Bye, R., Mata, R. (2017). Spasmolytic action of preparations and compounds from Hofmeisteria schaffneri. Natural Product Communications, 12, 475-476. DOI: https://doi.org/10.1177/1934578x1701200401.

29. Blanco, M.A., Colareda, G.A., Van Baren, C., Bandoni, A.L., Ringuelet, J., Consolini, A.E. (2013). Antispasmodic effects and composition of the essential oils from two South American 
chemotypes of Lippia alba. Journal of Ethnopharmacology, 149, 803-809. DOI: https:// doi.org/10.1016/j.jep.2013.08.007.

30. Menezes, P.M.N., de Oliveira, H.R., Brito, M.C., de Paiva, G.O., Ribeiro, L.A., Lucchese, A.M., Silva, F.S. (2019). Spasmolytic and antidiarrheal activities of Lippia thymoides (Verbenaceae) essential oil. Natural Product Research, 33, 2571-2573. DOI: https://doi.org/10.1080/14786419.2018.1457665.

31. Sadraei, H., Ghannadi, A., Malekshahi, K. (2003) Relaxant effect of essential oil of Melissa officinalis and citral on rat ileum contractions. Fitoterapia, 74, 445-452. DOI: https://doi.org/10.1016/S0367-326X (03)00109-6.

32. Souza, F.V.M., Da Rocha, M.B., De Souza, D.P., Marçal, R.M. (2013). Carvone: Antispasmodic effect and mode of action. Fitoterapia, 85, 20-24. DOI: https://doi.org/10.1016/j.fitote.2012.10.012.

33. De Sousa, D.P., Júnior, G.A.S., Andrade, L.N., Calasans, F.R., Nunes, X.P., Barbosa-Filho, J.M., Batista, J.S. (2008). Structure and spasmolytic activity relationships of monoterpene analogues found in many aromatic plants Zeitschrift fur Naturforsch - Sect C. Journal of Biosciences, 63,808812. DOI: https://doi.org/10.1515/znc-2008-11-1205.

34. Janbaz, K.H., Hamid, I., Gilani, A.U.H., Qadir, M.I. (2014). Spasmolytic, bronchodilator and vasodilator activities of aqueous methanolic extract of Ocimum basilicum. International Journal of Agriculture \& Biology, 16, 321-327. DOI: http:// www.fpublisher.org.

35. Madeira, S.V.F., Matos, F.J.A., Leal-Cardoso, J.H., Criddle, D.N. (2002). Relaxant effects of the essential oil of Ocimum gratissimum on isolated ileum of the guinea pig. Journal of Ethnopharmacology, 81, 1-4. DOI: https:// doi.org/10.1016/S0378-8741(02)00049-1.

36. Souza, S.D.F., Franca, C.S.L., Niculau, E.S., Costa, L.C.B., Pinto, J.E.B., Alves, P.B., Marçal, R.M. (2015). Antispasmodic effect of Ocimum selloi essential oil on the guinea pig ileum. Natural Product Research, 29, 2125-2128. DOI: https:// doi.org/10.1080/14786419.2014.989392.

37. Makrane, H., Aziz, M., Mekhfi, H., Ziyyat, A., Bnouham, M., Legssyer, A., Gressier, B., Eto, B. (2018). Antispasmodic and myorelaxant activity of organic fractions from Origanum majorana L. on intestinal smooth muscle of rodents. European Journal of Medicinal Plants, 23, 1-11. DOI: https:// doi.org/10.9734/ejmp/2018/41075.

38. Câmara, C.C., Nascimento, N.R.F., Macêdo-Filho, C.L., Almeida, F.B.S., Fonteles, M.C. (2003).
Antispasmodic effect of the essential oil of Plectranthus barbatus and some major constituents on the guinea-pig ileum. Planta Medica, 69, 10801085. DOI: https://doi.org/10.1055/s-2003-45186.

39. Tirapelli, C.R., de Andrade, C.R., Cassano, A.O., De Souza, F.A., Ambrosio, S.R., da Costa, F.B., de Oliveira, A.M. (2007). Antispasmodic and relaxant effects of the hydroalcoholic extract of Pimpinella anisum (Apiaceae) on rat anococcygeus smooth muscle. Journal of Ethnopharmacology, 110, 23-29. DOI: https://doi.org/10.1016/j.jep.2006.08.031.

40. Baratta, M.T., Dorman, H.J.D., Deans, S.G., Figueiredo, A.C., Ruberto, G. (1998). Antimicrobial and antioxidant properties of some commercial essential oils. Flavour and Fragrance Journal, 13, 235 -244. DOI: https:doi.org/10.1002/sici.1099.

41. Khan, A., Najeeb, R., Alkharfy, K.M., Gilani, A.H. (2011). Antidiarrheal and antispasmodic activities of Salvia officinalis are mediated through activation of $\mathrm{K}+$ channels. Bangladesh Journal of Pharmacology, 6, 111-116. DOI: https:// doi.org/10.3329/bjp.v6i2.9156.

42. Hajhashemi, V., Sadraei, H., Ghannadi, A.R., Mohseni, M. (2000). Antispasmodic and antidiarrhoeal effect of Satureja hortensis L. essential oil. Journal of Ethnopharmacology, 71, 187-192. DOI: https://doi.org/10.1016/S0378-8741(99)00209-3.

43. Souz,a I.L.L., Correia, A.C., Araujo, L.C., Vasconcelos, L.H.C., Silva, M.C.C., Costa, V.C., Tavares, J.F., Paredes-Gamero, E.J., Cavalcante, F.A., Silva, B.A. (2015). Essential oil from Xylopia frutescens Aubl. reduces cytosolic calcium levels on guinea pig ileum: Mechanism underlying its spasmolytic potential. BMC Complementary and Alternative Medicine, 15, 1-10. DOI: https:// doi.org/10.1186/s12906-015-0849-3.

44. Correia, A.D.C., Ferreira, T.F., Martins, I.R.R., Macêdo, C.L., Monteiro, F.D.S., Costa, V.C.O., Tavares, J.F., Silva, M.S., Paredes-Gamero, E.J., Buri, M.V., Rigoni, V.L.S., Nouailhetas, V.L.A., Silva, B.A. (2015). Essential oil from the leaves of Xylopia langsdorfiana (Annonaceae) as a possible spasmolytic agent. Natural Product Research, 29, 980 -984. DOI: https:// doi.org/10.1080/14786419.2014.964706.

45. Burt, S. (2004). Essential oils: their antibacterial properties and potential applications in foods - a review. International Journal of Food and Microbiology, 94, 223-253. DOI: https:// doi.org/10.1016/j.ijfoodmicro.2004.03.022.

46. Radünz, M., Trindade, M.L.M., Camargo, T.M., Radünz, A.L., Borges, C.D., Gandra, E.A., Helbig, E. (2019). Antimicrobial and antioxidant activity of 
unencapsulated and encapsulated clove (Syzygium aromaticum, L.) essential oil. Food Chemistry, 276, 180-186. DOI: https://doi.org/10.1016/ j.foodchem.2018.09.173.

47. Burt, S. (2004). Essential oils: their antibacterial properties and potential applications in foods - a review. International Journal of Food and Microbiology, 94, 223-253. DOI: https:// doi.org/10.1016/j.ijfoodmicro.2004.03.022.

48. Lee, S.J., Han, J.I., Lee, G.S., Park, M.J., Choi, I.G., $\mathrm{Na}$, K.J., Jeung, E.B. (2007). Antifungal effect of eugenol and nerolidol against Microsporum gypseum in a guinea pig model. Biological and Pharmaceutical Bulletin, 30, 184-188. DOI: https:// doi.org/10.1248/bpb.30.184.

49. Kubo, I., Fujita, K., Kubo, A., Nihei, K., Ogura, T. (2004). Antibacterial activity of coriander volatile compounds against Salmonella choleraesuis. Journal of Agriculture and Food Chemistry, 52, 3329-3332. DOI: https://doi.org/10.1021/jf0354186.

50. Bagamboula, C.F., Uyttendaele, M., Debevere, J. (2004). Inhibitory effect of thyme and basil essential oils, carvacrol, thymol, estragol, linalool and p-cymene towards Shigella sonnei and $S$. flexneri. Food and Microbiology, 21, 33-42. DOI: https://doi.org/10.1016/S0740-0020(03)00046-7.

51. Dusan, F., Marian, S., Katarina, D., Dobroslava, B. (2006). Essential oils-their antimicrobial activity against Escherichia coli and effect on intestinal cell viability. Toxicology In Vitro, 20, 1435-1445.

52. Zhang, Y., Liu, X., Wang, Y., Jiang, P., Quek, S.Y. (2016). Antibacterial activity and mechanism of cinnamon essential oil against Escherichia coli and Staphylococcus aureus. Food Control, 59, 282-289. DOI: j.foodcont.2015.05.032

53. Lin, L., Zhu, Y., Thangaraj, B., Abdel-Samie, M.A.S., Cui, H. (2018). Improving the stability of thyme essential oil solid liposome by using $\beta$ cyclodextrin as a cryoprotectant. Carbohydrate Polymers, 188, 243-251. DOI: https:// linkinghub.elsevier.com/retrieve/pii/ S0144861718301486

54. Bouchra, C., Achouri, M., Hassani, L.M.I., Hmamouchi, M. (2003). Chemical composition and antifungal activity of essential oils of seven Moroccan labiatae against Botrytis cinerea Pers: Fr. Journal of Ethnopharmacology, 89, 165-169.

55. Brochot, A., Guilbot, A., Haddioui, L., Roques, C. (2017). Antibacterial, antifungal, and antiviral effects of three essential oil blends. Microbiology Open, 6(4), e00459.
56. Battistini, R., Rossini, I., Ercolini, C., Goria, M., Callipo, M.R., Maurella, C., Pavoni, E., Serracca, L. (2019). Antiviral activity of essential oils against hepatitis A virus in soft fruits. Food Environmental Virology, 11, 90-95. DOI: http://dx.doi.org/10.1007/ s12560-019-09367-3

57. Garozzo, A., Timpanaro, R., Bisignano, B., Furneri, P.M., Bisignano, G., Castro, A. (2009). In-vitro antiviral activity of Melaleuca alternifolia essential oil. Letters in Applied Microbiology, 49, 806-808.

58. Guleria, S., Tiku, A.K., Koul, A., Gupta, S., Singh, G., Razdan, V.K. (2013). Antioxidant and antimicrobial properties of the essential oil and extracts of Zanthoxylum alatum grown in Northwestern Himalaya. Scientific World Journal, 1, 1-9.

59. Jaradat, N., Adwan, L., K'aibni, S., Shraim, N., Zaid, A.N. (2016). Chemical composition, anthelmintic, antibacterial and antioxidant effects of Thymus bovei essential oil. BMC Complementary and Alternative Medicine, 16, 1-7. DOI: http:// dx.doi.org/10.1186/s12906-016-1408-2

60. Prashar, A., Locke, I.C., Evans, C.S. (2004). Cytotoxicity of lavender oil and its major components to human skin cells. Cell Proliferation, $37,221-229$.

61. Oukerrou, M.A., Tilaoui, M., Mouse, H.A., Bouchmaa, N., Zyad, A. (2017). Differential cytotoxic activity of essential oil of Lippia citriodora from different regions in Morocco. Chemistry $\mathcal{E}$ Biodiversity, 14, 1-11.

62. Turkez, H., Tozlu, O.O., Lima, T.C., Emmanuela, A., De Brito, M., De Sousa, D.P. (2018). A comparative evaluation of the cytotoxic and antioxidant activity of Mentha crispa essential oil, its major constituent rotundifolone and analogues on human glioblastoma. Oxidative Medicine and Cellular Longevity, 1, 1-12.

63. Ramak, P., Reza, G. (2018). Chemical composition, cytotoxic e ff ect and antimicrobial activity of Stachys koelzii Rech essential oil against periodontal pathogen Prevotella intermedia. Microbial Pathogenesis, 124, 272-278. DOI: https:// doi.org/10.1016/j.micpath.2018.08.010

64. Han, X., Parker, T.L. (2017). Antiinflammatory activity of cinnamon (Cinnamomum zeylanicum) bark essential oil in a human skin disease model. Phytotherapy Research, 1038, 1034-1038.

65. Silva, G.L.D.A., Luft, C., Lunardelli, A., Amaral, R.H. (2015). Antioxidant, analgesic and antiinflammatory effects of lavender essential oil. Anais da Academia Brasileira de Ciências, 87, 13971408. 
66. Adeosun, T.E., Ogunwande, I.A., Avoseh, O.N., Raji, I.P., Lawal, O.A. (2017). Composition and anti -inflammatory activity of essential oil of Jatropha curcas. Natural Product Communications, 12, 4-5.

67. Han, X., Parker, T.L. (2017). Anti-inflammatory activity of clove (Eugenia caryophyllata) essential oil in human dermal fibroblasts. Pharmaceutical Biology, 55, 1619-1622.

68. Sales, S., Brito, A., De Araujo, G., Bezerra, F., Rose, I., De Menezes, A.,Regina, M. (2018). Antiparasitic activity and essential oil chemical analysis of the Piper tuberculatum Jacq fruit. Iranian Journal of Pharmaceutical Research, 17, 268-275.

69. Soares, B.V., Neves, L.R., Ferreira, O., Sidney, M., Oliveira, B. (2016). Antiparasitic activity, histopathology and physiology of Colossoma macropomum (tambaqui) exposed to the essential oil of Lippia sidoides (Verbenaceae). Veterinary Parasitology, 234, 49-56. DOI: http:// dx.doi.org/10.1016/j.vetpar.2016.12.012

70. Griseb, S., Guti, Y.I., Villa, A., Satyal, P., Cos, P., Monzote, L., Setzer, W.N. (2019). Chemical composition, antimicrobial and antiparasitic screening of the essential oil from Phania matricarioides (Spreng.) Griseb. Molecules, 24, 1-11.

71. Sinott, F.A., Sena-Lopes, A., Leal, K.S., Thais de Oliveira Silva, M., Cardoso de Freitas, M., Quintana de Moura, M., Aires-Berne, M.E., Borsuk, S. (2018). Essential oil from Brazilian Red Propolis exhibits anthelmintic activity against larvae of Toxocara cati. Experimental Parasitology, 200, 37-41. DOI: https://doi.org/10.1016/ j.exppara.2019.03.014

72. Wakabayashi, K.A.L., De Melo, N.I., Aguiar, D.P., De Oliveira, P.F., Groppo, M., Da Silva Filho, A.A., Rodrigues, V., Cunha, W.R., Tavares, D.C., Magalhaes, L.G., Crotti, A.E.M. (2015). Anthelmintic effects of the essential oil of fennel (Foeniculum vulgare Mill., Apiaceae) against Schistosoma mansoni. Chemistry \& Biodiversity, 12, 1105-1114.

73. Plata-Rueda, A., Martínez, L.C., Dos, S.M.H., Fernandes, F.L., Wilcken, C.F., Soares, M.A., Serrao, J.E., Zanuncio, J.C. (2017). Insecticidal activity of garlic essential oil and their constituents against the mealworm beetle, Tenebrio molitor Linnaeus (Coleoptera: Tenebrionidae). Scientific Reports, 7, 1-11. DOI: http://dx.doi.org/10.1038/ srep46406

74. Benelli, G., Govindarajan, M., Rajeswary, M., Vaseeharan, B., Alyahya, S.A., Alharbi, N.S., Kadaikunnan, S., Khaled, J.M., Maggi F. (2018). Insecticidal activity of camphene, zerumbone and $\alpha$-humulene from Cheilocostus speciosus rhizome essential oil against the Old-World bollworm, Helicoverpa armigera. Ecotoxicology and Environmental Safety, 148, 781-786. DOI: https:// doi.org/10.1016/j.ecoenv.2017.11.044

75. Magierowicz, K., Gorska-Drabik, E., Sempruch, C. (2019). The insecticidal activity of Satureja hortensis essential oil and its active ingredient -carvacrol against Acrobasis advenella (Zinck.) (Lepidoptera, Pyralidae). Pesticide Biochemistry and Physiology, 153, 122-128. DOI: https://doi.org/10.1016/ j.pestbp.2018.11.010

76. Reis, D., Jones, T. (2017). Aromatherapy: Using essential oils as a supportive therapy. Clinical Journal of Oncology Nursing, 21, 16-19.

77. Han, C., Li, F., Tian, S., Liu, Y., Xiao, H., Wu, X., Zhang, W., Zhang, W., Mao, M. Beneficial effect of compound essential oil inhalation on central fatigue. BMC Complementary and Alternative Medicine, 18, 309-311.

78. Du, J.P., Liu, Y.T., Wu, Y.J., Wu, H.H., Xu, Y.T. (2017). Fast-onset antidepressant potentials of essential oil of herbs. China Journal of Chinese Materia medica, 42, 2006-2016.

79. Van der Weijden, G.A., Hioe, K.P.K. (2005). A systematic review of the effectiveness of selfperformed mechanical plaque removal in adults with gingivitis using a manual toothbrush. Journal of Clinical Periodontology, 32, 214-228.

80. Serbiak, A.B., Fourre, T., Anthony, R., Gambogi, R.J. (2017). In vitro efficacy of essential oil mouthrinse versus dentifrices. Journal of Dentistry, $8,1-24$.

81. Haas, A.N., Wagner, T.P., Muniz, F.W., Fiorini, T., Cavagni, J.C.R. (2017). Effect of essential oil mouthwashes on plaque and gingivitis. British Dental Journal, 55, 7-15.

82. Lemos-Júnior, C.A., Villoria, G.E.M. (2008). Reviewed evidence about the safety of the daily use of alcohol-based mouthrinses. Brazilian Oral Research, 22, 24-31.

83. Lynch, M.C., Cortelli, S.C., McGuire, J.A., Zhang, J., Ricci-Nittel, D., Mordas, C.J., Aquino, D.R., Cortelli, J.R. (2018). The effects of essential oil mouthrinses with or without alcohol on plaque and gingivitis: A randomized controlled clinical study. BMC Oral Health, 18, 6-16.

84. Charles, C., Gallob, J.T., Vegas, L. (2012). Antiplaque and antigingivitis efficacy of an alcohol-free essential-oil containing mouthrinse@: A 2-week clinical trial. American Journal of Dentistry, 25, 195-198. 
85. Herman, A., Herman, A.P. (2014). Essential oils and their constituents as skin penetration enhancer for transdermal drug delivery: a review. Journal of Pharmacy and Pharmacology, 1, 1-13.

86. Jiang, Q., Wu, Y., Zhang, H., Liu, P., Yao, J., Yao, P., Chen, J., Duan, J. Development of essential oils as skin permeation enhancers: Penetration enhancement effect and mechanism of action. Pharmaceutical Biology, 55, 1592-600. DOI: http:// dx.doi.org/10.1080/13880209.2017.1312464

87. Chen, J., Jiang, Q., Wu, Y., Liu, P., Yao, J., Lu, Q., Zhang, H., Duan, J. (2015). Potential of essential oils as penetration enhancers for transdermal administration of ibuprofen to treat dysmenorrhoea. Molecules, 20, 18219-18236.

88. De Matos, S.P., Teixeira, H.F., De Lima, A.A.N., Veiga-Junior, V.F., Koester, L.S. (2019). Essential oils and isolated terpenes in nanosystems designed for topical administration: A review. Biomolecules, 9, 1-19.

89. Johnson, S., Boren, K. (2012). Topical and oral administration of essential oils - safety issues. Aromatopia, 22, 43-48.

90. Zhao, Y., Wang, C., Chow, A.H.L., Ren, K., Gong, T., Zhang, Z., Zheng, Y. Self-nanoemulsifying drug delivery system (SNEDDS) for oral delivery of Zedoary essential oil: Formulation and bioavailability studies. International Journal of Pharmaceutics, 383, 170-177.

91. Gracioso, J.S., Haun, M., Nunes, D.S. (2000). Gastroprotective effect of essential oil from Croton cajucara. Journal of Ethnopharmacology, 69, 229-234.

92. Turek, C., Stintzing, F.C. (2013). Stability of essential oils: A review. Comprehensive Reviews in Food Science \& Food Safety, 12, 40-53.

93. Inal, O. (2012). Nanomaterials and cosmetics. Journal of Faculty of Pharmacy, 42, 43-47.

94. Pathak, C., Vaidya, F.U., Pandey, S.M. (2019). Mechanism for development of nanobased drug delivery system. Applications of Targeted Nano Drugs and Delivery Systems, 1, 35-67. DOI: http:// dx.doi.org/10.1016/B978-0-12-814029-1.00003-X

95. Gupta, M., Sharma, V., Chauhan, N.S. (2017). Nanotechnology for oral delivery of anticancer drugs: an insight potential. Nanostructures for Oral Medicine, 1, 467-510. DOI: http:// dx.doi.org/10.1016/B978-0-323-47720-8/00017-1

96. Khayata, N., Abdelwahed, W., Chehna, M.F., Charcosset, C., Fessi, H. (2012). Preparation of vitamin E loaded nanocapsules by the nanoprecipitation method: From laboratory scale to large scale using a membrane contactor.
International Journal of Pharmaceutics, 423, 419-427.

DOI:

http://dx.doi.org/10.1016/

j.ijpharm.2011.12.016

97. Natrajan, D., Srinivasan, S., Sundar, K., Ravindran, A. (2015). Formulation of essential oil-loaded chitosan e alginate nanocapsules. Journal of Food and Drug Analysis, 23, 560-568. DOI: http:// dx.doi.org/10.1016/j.jfda.2015.01.001

98. Rizvi, S.A.A., Saleh, A.M. (2018). Applications of nanoparticle systems in drug delivery technology. Saudi Pharmaceutical Journal, 26, 64-70. DOI: https://doi.org/10.1016/j.jsps.2017.10.012

99. Chifiriuc, M.C., Kamerzan, C., Lazar, V. Chapter 12 - Essential oils and nanoparticles: New strategy to prevent microbial biofilms. In: Ficai A, Grumezescu AM, editors. Nanostructures for Antimicrobial Therapy [Internet]. Elsevier; 2017. p. 279-91. (Micro and Nano Technologies). DOI: http://www.sciencedirect.com/science/article/pii/ B9780323461528000123

100. Varshosaz, J., Farzan, M. (2015). Nanoparticles for targeted delivery of therapeutics and small interfering RNAs in hepatocellular carcinoma. World Journal of Gastroenterology, 21, 12022-12041.

101. Detoni, C., Cabral-albuquerque, E. (2013). The use of nanotechnology as an approach for essential oilbased formulations with antimicrobial activity In Microbial Pathogens and Strategies for Combating Them (Méndez-Vilas, A., ed.) Formatex Research Center Pulisher, pp. 1364-1374.

102. Ferreira, T.P., Haddi, K., Corrêa, R.F., Zapata, V.L., Piau, T.B., Souza, L.F., Santos, S.M.G., Oliveira, E.E., Jumbo, L.O., Ribeiro, B.M. and Grisolia, C.K., (2019). Prolonged mosquitocidal activity of Siparuna guianensis essential oil encapsulated in chitosan nanoparticles. PLoS Neglected Tropical Diseases, 13(8), e0007624.

103. Saporito, F., Sandri, G., Bonferoni, M.C., Rossi, S., Cornaglia, A.I., Mannucci, B., Grisoli, P., Vigani, B. (2018). Essential oil-loaded lipid nanoparticles for wound healing. International Journal of Nanomedicine, 13, 175-186.

104. Bilia, A.R., Guccione, C., Isacchi, B., Righeschi, C., Firenzuoli, F., Bergonzi, M.C. (2014). Essential oils loaded in nanosystems: A developing strategy for a successful therapeutic approach. Evidence-based Complementary and Alternative Medicine, 1, 1-14.

105. Dobziuk, H. (2006). Molecules with Holes Cyclodextrins In: Cyclodextrins and their complexes, pp. 1-29.

106. Fravel BW. Pyrans and their Benzo Derivatives: Applications. In: Katritzky AR, Ramsden CA, 
Scriven EF V, Taylor RJK, editors. Comprehensive Heterocyclic Chemistry III. Oxford: Elsevier; 2008. pp. 701-726. Available from: http:// www.sciencedirect.com/science/article/pii/ B978008044992000609X

107. Nurunnabi, M., Revuri, V., Huh, K.M., Lee, Y. (2017). Polysaccharide based nano/ microformulation: an effective and versatile oral drug delivery system. In: Andronescu E, Grumezescu AM, editors. Nanostructures for Oral Medicine. Elsevier, pp. 409-33. (Micro and Nano Technologies). Available from: http:// www.sciencedirect.com/science/article/pii/ B9780323477208000158

108. Salustio, P.J., Pontes, P., Conduto, C., Sanches, I., Carvalho, C., Arrais, J., Marques, H.M.C. (2011). Advanced technologies for oral controlled release: Cyclodextrins for oral controlled release. AAPS PharmSciTech, 12, 1276-1292.

109. Capelezzo, A.P., Mohr, L.C., Dalcanton, F., de Mello, J.M.M, Fiori, M.A. (2018). $\beta$-Cyclodextrins as encapsulating agents of essential oils. Cyclodextrin [Internet]. Rijeka: IntechOpen; DOI: https://doi.org/10.5772/intechopen.73568

110. Babaoglu, H., Bayrak, A., Ozdemir, N., Ozgun, N. (2017). Encapsulation of clove essential oil in hydroxypropyl beta-cyclodextrin for characterization, controlled release, and antioxidant activity. Journal of Food Processing and Preservation, 41, e13202.

111. Lu, W., Huang, D., Wang, C.C.R., Yeh, C., Tsai, J., Huang, Y., Li, P. Preparation, characterization and antimicrobial activity of nanoemulsions incorporating citral essential oil. Journal of Food and Drug Analysis, 1, 1-8. DOI: http:// dx.doi.org/10.1016/j.jfda.2016.12.018

112. Pathania, R., Khan, H., Kaushik, R., Khan, M.A. (2018). Current research in nutrition and food science essential oil nanoemulsions and their antimicrobial and food applications. Current Research in Nutrition and Food Science, 6, 626-643.

113. Gasco, M.R., Gallarate, M., Pattarino, F. (1991). In vitro permeation of azelaic acid from viscosized microemulsions. International Journal of Pharmaceutics, 69, 193-196.

114. Kriwet, K., Müller-Goymann, C.C. (1995). Diclofenac release from phospholipid drug systems and permeation through excised human stratum corneum. International Journal of Pharmaceutics, 125, 231-242.

115. Ghosh, V., Saranya, S., Mukherjee, A., Chandrasekaran, N. (2013). Cinnamon oil nanoemulsion formulation by ultrasonic emulsification: investigation of its bactericidal activity. Journal of Nanoscience and Nanotechnology, $13,114-122$.

116. Nastiti, C.M.R.R, Ponto, T., Abd, E., Grice, J.E., Benson, H.A.E., Roberts, M.S. (2017). Topical nano and microemulsions for skin delivery. Pharmaceutics, 9, 1-25.

117. Surassmo, S., Srinuanchai, W. (2013). Formulation Development of plai nanoemulsion of surfactant combinations. Chiang Mai Journal of Science, 40, 994 -999 .

118. Musthaba, S.M., Baboota, S., Ahmed, S., Ahuja, A., Ali, J. (2009). Status of novel drug delivery technology for phytotherapeutics Status of novel drug delivery technology for phytotherapeutics. Expert Opinion on Drug Delivery, 5247, 625-637.

119. Moghimipour, E., Aghel, N., Mahmoudabadi, A.Z., Ramezani, Z., Handali, S. (2012). Preparation and characterization of liposomes containing essential oil of Eucalyptus camaldulensis leaf. Jundishapur Journal of Natural Pharmaceutical Products, 7, 117-122.

120. Coimbra, M., Isacchi, B., Van, B.L., Torano, J.S., Ket, A., Wu, X., Broere, F., Metselaar, J.M., Rijcken, C.J.F., Storm, G., Bilia, R., Schiffelers, R.M. (2011). Improving solubility and chemical stability of natural compounds for medicinal use by incorporation into liposomes. International Journal of Pharmaceutics, 416, 433-442. DOI: https:// www.sciencedirect.com/science/article/pii/ S0378517311000871

121. Anwekar, H., Patel, S., Singhai, A.K. (2011). Liposome as drug carriers. International Journal of Pharmaceutics Life Sci, 2, 945-951.

122. Bulbake, U., Doppalapudi, S., Kommineni, N., Khan, W. (2017). Liposomal formulations in clinical use: An updated review. Pharmaceutics, 9, 1 -33 .

123. Chen, W., Cheng, F., Swing, C.J., Xia, S., Zhang, X. (2019). Modulation effect of core-wall ratio on the stability and antibacterial activity of cinnamaldehyde liposomes. Chemistry and Physics of Lipids, 223, 104790. DOI: https:// linkinghub.elsevier.com/retrieve/pii/ S0009308419300672

124. Risaliti, L., Kehagia, A., Daoultzi, E., Lazari, D., Bergonzi, M.C., Vergkizi-Nikolakaki, S., Hadjipavlou-Litina, D., Bilia, A.R. (2019). Liposomes loaded with Salvia triloba and Rosmarinus officinalis essential oils: In vitro assessment of antioxidant, antiinflammatory and 
antibacterial activities. Journal of Drug Delivery Science and Technology, 51, 493-498. DOI: https:// linkinghub.elsevier.com/retrieve/pii/ S1773224719300164

125. Sebaaly, C., Jraij, A., Fessi, H., Charcosset, C., Greige-gerges, H. (2015). Preparation and characterization of clove essential oil-loaded liposomes. FOOD Chemistry, 178, 52-62. DOI: http://dx.doi.org/10.1016/j.foodchem.2015.01.067

126. Radtke, M., Müller, R. H. (2001). Nanostructured lipid drug carriers. New Drugs, 2, 48-52.

127. Singh, S., Pandey, V.K., Tewari, R.P., Agarwal, V. (2011). Nanoparticle based drug delivery system: Advantages and applications. Indian Journal of Science and Technology, 4, 177-180.

128. Shah, N. V., Seth, A.K., Balaraman, R., Aundhia, C.J., Maheshwari, R.A., Parmar, G.R. (2016). Nanostructured lipid carriers for oral bioavailability enhancement of raloxifene: Design and in vivo study. Journal of Advcanced Research, 7, 423-434. DOI: http://dx.doi.org/10.1016/ j.jare.2016.03.002
129. Gupta, B., Yong, C.S., Kim, J.O. (2017). Solid matrix-based lipid nanoplatforms as carriers for combinational therapeutics in cancer. Journal of Pharmaceutical Investigation, 47, 461-473.

130. Sharma, A., Baldi, A. (2018). Nanostructured lipid carriers: A review. Developing Drugs Journal, 7, 112.

131. Naseri, N., Valizadeh, H., Zakeri-milani, P. (2015). Solid lipid nanoparticles and nanostructured lipid carriers: Structure, preparation and application. Tabriz University Medical Sciences, 5, 305-313. DOI: http://dx.doi.org/10.15171/apb.2015.043

132. Oehlke, K., Behsnilian, D., Mayer-miebach, E., Weidler, P.G., Greiner, R. (2017). Edible solid lipid nanoparticles (SLN) as carrier system for antioxidants of different lipophilicity. PLoS One, $12,1-18$.

133. McClements, D.J., Decker, E.A., Weiss, J. (2007). Emulsion-based delivery systems for lipophilic bioactive components. Journal of Food Science, 72, 109-124. 